\title{
POLYMORPHISM OF THE GENE GDF9 IN SHEEP OF PRIKATUN TYPE OF ALTAI MOUNTAINS BREED AND ITS CORRELATION WITH INDICES OF MEAT RATE PRODUCTIVITY
}

\author{
Marina I. Selionova ${ }^{1 *}$, Nikolay A. Podkorytov ${ }^{2}$ \\ Russian State Agrarian University - Moscow Timiryazev Agricultural Academy, Moscow, Russia \\ ${ }^{2}$ Altai Mountains Research Institute of Agriculture - \\ Branch of the Federal Altai Scientific Center of Agrobiotechnology, Altai Republic, Mayma settlement, Russia
}

\begin{abstract}
Keywords: sheep, genotype, growth factor gene, polymorphism, slaughter traits
Abstract

In recent decades in many countries of the world the development of sheep farming is determined by the efficiency of mutton production. One of the promising areas of selection improvement of sheep breeds of meat and meat \& wool productivity is an application of molecular-genetic methods. To obtain high-quality mutton it is advisable to use the Altai Mountains sheep breed, which features by high energy of growth of young animals and their adaptability to all-year-round pasture management. One of the candidate genes responsible for sheep meat productivity is the gene of growth differentiation factor-GDF9 (growth differentiation factor 9). The article presents the results of research of polymorphism of the gene GDF9 and its relation with the parameters of meat productivity in young sheep of Altai Mountains breed. It was found that the rams-carriers of AA genotype outperformed their peers of $A G$ and $G G$ genotypes in terms of pre-slaughter weight, carcass weight, meat yield and meat content ratio by 1.62 and $7.01 \mathrm{~kg}, 1.34$ and $3.98 \mathrm{~kg}(P<0.05), 1.21$ and $1.86 \mathrm{abs}$. percent, 0.16 and 0.39 units $(P<0.05)$ accordingly. The muscle tissue of rams of the desired genotype featured the highest content of protein, fat and, accordingly, energy value in comparison with AG and GG genotypes. The animals of AA genotype had the largest area of a rib eye and diameter of muscle fibers. The superiority over other genotypes achieved $1.55 \mathrm{~cm}^{2}$ and 1.98 microns in average. In addition the higher number of inter-fiber and inter-bundle inclusions of fat and lower content of connective tissue stipulated higher marbling score (MB)-higher by 3.32 points. The obtained data indicate that it is promising methods to increase the number of homozygotic animals in term of gene GDF9 by intended selection of parent animals whose genotype contains a desirable element for further improvement of quantitative and qualitative parameters of meat rate productivity in sheep of Altai Mountains breed.
\end{abstract}

\section{Introduction}

One of the relevant objectives of modern animal husbandry is an application of new methods for assessing the productivity characteristics of farm animals, directly based on genome analysis [1]. All over the world the large-scale studies are conducted, which studies are aimed to identify genes associated with economically useful features of animals [2]. Genetic differences are usually presented in the form of single-nucleotide polymorphisms (SNP), which allows using them as a molecular genetic marker, on which basis the animals can be taken for further selection [3].

It is known that both in breeding of farm animals as a whole and in a single herd, some individual animals have a low rate of productivity, some animals feature medium rate, and some - high, and a very small number of animals have the highest rate of productivity. It is these very animals which are of the greatest interest for the selection process. The development of molecular genetic methods, the possibility of simultaneous genotyping of dozens of loci in a single genome - together with the phenotypic assessment allows the breeder to select with much higher accuracy the valuable animals, which shall transmit their best economically valuable features to their offspring, thereby providing a significant acceleration of selection breeding progress. In addition, the molecular-genetic approach to genotyping avoids the manifestation of genetic regression, when an animal highly valuable for its own rate of productivity does not transmit its meat qualities to subsequent generations.

To increase meat productivity is important for sheep breeding, since in recent decades in many countries of the world the development of sheep breeding is determined by efficiency of mutton production. In its turn it leads to a steady increase of specialized meat breeds share and increasing demands on the very meat rate productivity for sheep of meat and wool breeds [4]. However, the markerassociated approach in selection of this type of productivity in sheep should be recognized as an insufficiently developed topic [5].

There are reports of associations of the myostatin (myostatin, MSTN), calpain-calpastatin cascade (calpain, $C A P N$, calpastatin, CAST), leptin (lepnin, LEP) genes with characteristics that determine the number and size of muscle fibers, features of hemolytic processes during meat maturation, and determine the degree of its tenderness and juiciness $[5,6,7,8,9,10]$. These genes are considered to be 
promising for their use in breeding programs to improve the meat rate productivity of sheep [11].

The genes of growth hormone $(\mathrm{GH})$ and growth differentiation factor 9 (GDF9) can be considered as candidate genes associated with the general development of muscle mass and, accordingly, with the meat rate productivity of sheep.

The growth hormone gene, or somatotropic hormone, is a key regulator of somatic growth throughout the life of an animal. Range of studies has demonstrated the relation of genetic variants of the gene with characteristics of meat rate production in sheep. Thus, in young animals of Salsk, Kalmyk and Edilbaevskaya breeds, the AB genotype stipulated the significantly higher parameters of carcass mass and its slaughter yield $[12,13]$. The nucleotide substitution at the point rs 400358099 of the $G H$ gene was associated with the growth energy of Texel breed lambs [14]. Different genotypes in the growth hormone $(G H)$ gene determined differences in live weight of young sheep of the dark-headed sheep breeds, as well as the breeds of Poll Dorset, Beluchi, Santa Yves and seven breeds of sheep from China $[15,16,17,18,19]$.

The majority of studies witness a link between the growth differentiation factor gene and the reproductive qualities and fertile multiplicity of sheep [20,21,22]. It has been shown that GDF9 expression is significantly higher in ovarian tissues than in other body tissues, while the protein product of the gene plays an important role in maintaining the normal folliculogenesis [23,24]. At the same time there are data on influence of different genetic variants of GDF9 on the live weight of young Salsk sheep, the dairy productivity of Avassi sheep, which indicates the feasibility of studying its polymophism and its relation with meat rate productivity indices $[25,26]$.

The Altai Mountains breed of sheep seems to be promising to obtain high-quality mutton. It belongs to the woolmeat type of productivity, it was bred by the method of complex long-term reproductive crossing in the 30-40s of the last century, it is perfectly adapted to all-year-round pasture management in cold climate and the highlands of Altai Republic. In the last decade the main direction of breeding activity has been aimed to improve the meat rate productivity of sheep while maintaining the quality characteristics of semi fine wool. The result of this work was the development of a new intra-breed type - Prikatun sheep, which belongs to the meat-wool type of productivity and currently seems to be the most promising one for breeding. The live weight of rams and ewes of Prikatun type of Altai Mountains breed in breeding farms is $94 \mathrm{~kg}$ and $58 \mathrm{~kg}$ respectively. The milk yield of ewes is more than $100 \mathrm{~kg}$ for four months period of lactation, the average daily weight gain of lambs during this period varies from $240 \mathrm{~g}$ to $260 \mathrm{~g}$, the live weight by the moment of lambs weaning from ewes is $30-32 \mathrm{~kg}$ [27].

For further improvement of the type it is quite appropriate to include genotyping by candidate genes of meat rate productivity into breeding programs. To determine the desired genotype it is necessary to apply comprehen- sive approach, including analysis of the quantitative and qualitative indices of meat, its nutritional and energy value, and consumer characteristics determined by chemical, biochemical, and microstructural indices [28].

The above was the rationale for the objective of this research - this is to study the indices of meat rate productivity, biochemical parameters of meat and histologi$\mathrm{cal}$ parameters of rib eye muscle ( $m$. longissimus dorsi) of sheep of Prikatun type of Altai Mountains breed in cases of different genotypes for gene GDF9.

\section{Materials and methods}

40 rams of Prikatun type of the Gorno-Altaisk (Altai Mountains) region were put under the research (private farm "Usoltsev N. A." of the Ust-Kansky district of Altai Republic). The studied material was DNA extracted from blood samples using the Diatom ${ }^{\text {tm }}$ DNAPrep kit (Isogen, Moscow) in amount of 3-5 micrograms $/ 100 \mathrm{mcl}$ with an OD of 260/280 from 1.6 to 2.0. Amplification of the site (exon) of the gene GDF9 (NCBI-National Center for Bio-technology Information ID is rs410123449, position 46547268 in the Oar_rambouillet_v1.0 assembly, 41770341 - in the Oar_v4 assembly.0) on a programmable thermal cycler "Tertsik" made by the company "DNA-technology" (Russia) with kits of "genePakPCRCore" (Isogen, Moscow) with the direct primer - 5'-gaa-gac-tgg-tat-ggg-gaa-atg- 3 ' and the reverse primer 5'-cca-atc-tgc-tcc-tac-aca-cct-3'. The presence of amplicons and their quality were preliminarily evaluated after electrophoresis in $2.0 \%$ agarose gel. The samples were restricted with BstHH1 endonuclease and the following genotypes were identified: AA, AG, and GG (Figure 1).

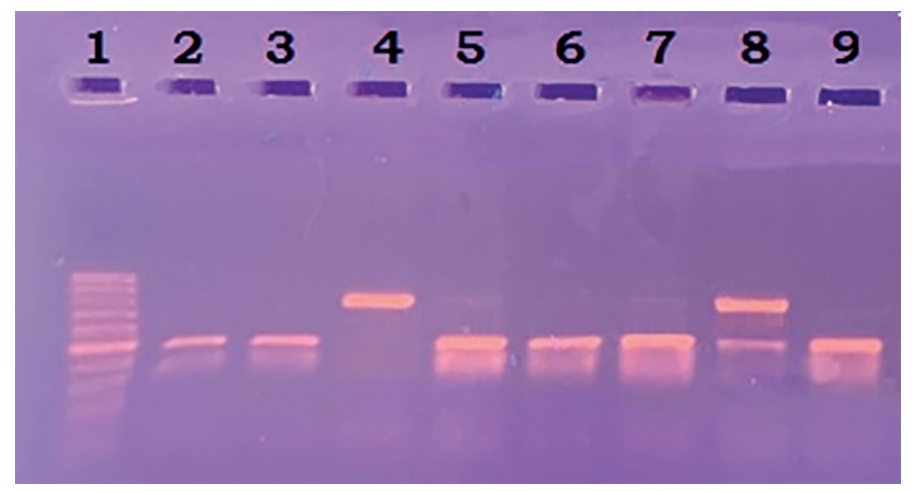

Figure 1. Electrophoregram of the results of PCR-RFLP analysis of the gene GDF9 in V 2.0\% agarose gel: 1-DNA marker 50 bp (Isogenic) 4-AA genotype; 8-AG genotype; 2, 3, 5, 6, 7, 9 - genotype GG

The occurrence frequency of genotypes and alleles was determined in accordance with the Methodological Recommendations "System of integrated assessment of the genetic potential of breeding animals" [29].

The meat rate productivity was studied on the basis of results of the rams slaughter parameters at the age of 7 months. In each genetic variant - AA, AG, GG - three animals were slaughtered, which animals corresponded to the average live weight in their group.

The pre-slaughter live weight was measured by weighing the animals after 24 hours of starvation, with an accuracy 
of $0.1 \mathrm{~kg}$. The mass of the carcass was determined by weighing the carcass together with kidneys and perinephral fat. The carcass yield was determined by the ratio of the carcass mass to the pre-slaughter live weight after 24 hours of starvation, expressed as a percentage. Slaughter masswas determined by summing the mass of an exsanguinated carcass without a head, skin, tail, internal organs, limbs cut off at the hock and wrist joints, and without internal fat. The mass of internal fat was determined by the total amount of pelvic, renal, intestinal, gastric, and diaphragmatic fat. The slaughter yield was calculated as the ratio of the slaughter mass to the pre-slaughter mass, expressed as a percentage. The meat content coefficient was determined by the ratio of the mass of the boneless meat to the mass of bones, expressed as percentage. The boneless meat coefficient was determined by separating the muscle tissue from the bone tissue and their weighing with an accuracy of $0.01 \mathrm{~kg}$.

Some indices of meat rate productivity of young sheep of Altai Mountains breed of different genotypes were used from the experiment, where these indices were studied when comparing animals for two genes-GDF9 and CAST [30] simultaneously.

During the control slaughter the rams meat samples were taken from the main topographic areas of the carcass for the preparation of an average sample and chemical analysis, as well as samples of the rib eye muscle ( $m$. longissimus dorsi) were prepared for histological studies.

The amount of moisture in the average sample of minced meat was determined according to GOST 33319-2015 " "Meat and meat products. Method for determination of moisture content». The sample was minced and mixed by meat homogenizer, dried in a drying chamber till a constant air-dry mass at a temperature of $103 \pm 2{ }^{\circ} \mathrm{C}$. The mass fraction of moisture, expressed as a percentage, was determined by the difference in the weight before and after drying. The amount of fat was determined according to GOST 23042-2015 "Meat and meat products. Methods of fat determination", by extracting the fat from the sample with petroleum ether in a Soxlet device, followed by its drying to a constant mass and determining the percentage difference. The amount of protein was determined according to GOST 25011-20173 "Meat and meat products. Protein determination methods", using the method of Kjeldahl, by the amount of nitrogen formed during the mineralization of organic substances and its conversion to protein applying coefficient of 6.25 . The caloric content was determined by calculation according to the formula of V. M. Alexandrov:

where

$$
C=[D-(F+A)] \times 4,1+(F \times 9,3),
$$

$C$ - caloric content, kcal;

$D, A, F$ - respectively, the amount of dry matter, ash, fat.

\footnotetext{
${ }^{1}$ GOST 33319-2015. "Meat and meat products. Method for determination of moisture content". Moscow: Standartinform, 2018. - 14 p. (In Russian)

${ }^{2}$ GOST 23042-2015 "Meat and meat products. Methods of fat determination". Moscow: Standartinform, 2019. - 8 p. (In Russian)

${ }^{3}$ GOST 25011-2017 "Meat and meat products. Protein determination methods”. Moscow: Standartinform, 2018. — 14 p. (In Russian)
}

For histological analysis, the samples were fixed in a $10 \%$ solution of neutral formalin, then compacted by gelatin pouring. The slices of 7-8 microns thick were obtained by freezing microtome. Structural components of the muscle tissue were defined by hematoxylin staining by Caracci with Sudan III according to Ehrlich method. The area of the muscle bundle, the quantity of muscle fibers in the bundle, the diameter of the muscle fiber and the bundle, the ratio of muscle and connective tissue were defined according to GOST 19496-2013" "Meat and meat products. Method of histological study".

The resulting numerical material was biometrically processed using the software Microsoft Office and BIOSTAT. Based on the average values and standard errors, the reliability of the difference between the average values was calculated using the Student's criterion.

\section{Results and discussion}

Genotyping of sheep of Altai Mountains breed of Prikatun type revealed that the polymorphism of the gene GDF9 is represented by A and G alleles. At the same time, the $\mathrm{G}$ allele and the GG genotype featured high prevalence, their occurrence frequency was 0.73 and 0.55 , respectively. Whereas the occurrence frequency of allele $A$ and genotypes AG and AA was $0.27 ; 0.35$ and 0.10 (Table 1 ).

Table 1. Occurrence of frequency of genotypes and alleles of the gene GDF9 in sheep of Altai Mountains breed of Prikatun type

\begin{tabular}{|c|c|c|c|}
\hline Genotype & $\begin{array}{c}\text { Number } \\
\text { of animals }\end{array}$ & \multicolumn{2}{|c|}{ Occurrence frequency } \\
\hline Of genotype & Of allele \\
\hline AA & 4 & 0.10 & \\
\hline GG & 14 & 0.35 & A 0.27 \\
\hline
\end{tabular}

The results obtained are similar to the data on the GDF9 polymorphism obtained by other researchers in the study of sheep breeds of Russian and foreign selection breed. Thus, in sheep of the Salsk and Romanov breeds, the $G$ allele and the $G G$ genotype also had a high frequency of occurrence 0.95 and $0.90,0.80$ and 0.61 , respectively. At the same time the occurrence of heterozygous AG genotype was detected with a low and medium frequency of 0.10 and 0.39 respectively [31]. In Hissar sheep the $G G$ genotype was found in 96.3\% of cases, and in Avassi breed - in 80.0\% [26,32].

The comparative analysis of the slaughter parameters of young sheep of Altai Mountains breed of different genotypes for the gene GDF9 at 7 months of age revealed that the AA-genotype rams were superior in comparison with their peers of the AG, GG-genotypes in terms of preslaughter weight, carcass weight, slaughter yield and meat ratio, respectively by 1.62 and $7.01 \mathrm{~kg} ; 1.34$ and $3.98 \mathrm{~kg}$ $(\mathrm{P}<0.05) ; 1.86$ and 1.21 abs. percent, 0.16 and 0.39 units $(\mathrm{P}<0.05)$ (Table 2).

\footnotetext{
${ }^{4}$ GOST 19496-2013 "Meat and meat products. The method of histological study" Moscow: Standartinform, 2019. — 12 p. (In Russian)
} 
Table 2. Slaughter parameters of Altai Mountains rams of Prikatun type with different genotypes according to the gene GDF9, in the age of 7 months

\begin{tabular}{|c|c|c|c|}
\hline \multirow{2}{*}{ Parameters } & \multicolumn{3}{|c|}{ Genotype } \\
\hline & AA & $\mathrm{AG}$ & GG \\
\hline $\begin{array}{l}\text { Pre-slaughter live } \\
\text { weight, kg }\end{array}$ & $46.33 \pm 2.18^{* 1}$ & $44.71 \pm 2.99^{* 2}$ & $39,32 \pm 2.78$ \\
\hline Weight of a carcass, $\mathrm{kg}$ & $22.17 \pm 0.94^{* 1}$ & $20.83 \pm 1.37$ & $18.19 \pm 0.84$ \\
\hline Carcass yield, $\%$ & $47.86 \pm 0.17^{\star 1}$ & $46.65 \pm 0.12$ & $46.00 \pm 0.26$ \\
\hline $\begin{array}{l}\text { Weight of internal } \\
\text { fat, } g\end{array}$ & $744.0 \pm 112.62$ & $619.2 \pm 85.17$ & $709.3 \pm 65.43$ \\
\hline Slaughter weight, kg & $22.91 \pm 2.76$ & $21.45 \pm 1.30$ & $18.89 \pm 1.20$ \\
\hline Meat rate productivity & $4.10 \pm 0.01$ & $3.94 \pm 1.19$ & $3.71 \pm 0.26$ \\
\hline Slaughter yield, \% & $49.44 \pm 0.28$ & $48.04 \pm 0.22$ & $47.97 \pm 0.24$ \\
\hline
\end{tabular}

The obtained results allow to conclude that in order to increase meat rate productivity, it is advisable to select the animals which carry the A allele. This will allow obtaining a greater number of homozygous AA individuals and, accordingly, their specific weight in the herd, which will ultimately affect its overall level of meat productivity.

The results of the comparative analysis of chemical analysis indices of average sample of minced meat obtained from animals of different genotypes also confirm the above information. The superiority of the AA genotype was established in protein, fat, and caloric content over the
AG and GG genotypes by 1.19 and $1.30 \% ; 1.24$ and $0.81 \%$; 164.16 and $128.63 \mathrm{kcal}$ respectively (Table 3 ).

Table 3. Chemical analysis of mutton from rams of Altai Mountains of Prikatun type of different genotypes by the gene GDF9

\begin{tabular}{|l|c|c|c|}
\multicolumn{1}{|c|}{ Parameter } & \multicolumn{3}{|c}{ Genotype } \\
\hline Moisture, \% & AA & AG & GG \\
\hline Dry matter, \% & $31.20 \pm 0.19$ & $28.78 \pm 0.16$ & $29.10 \pm 0.15$ \\
\hline Protein, \% & $15.42 \pm 0.19$ & $14.23 \pm 0.17$ & $14.12 \pm 0.14$ \\
\hline Fat, \% & $14.82 \pm 0.18$ & $13.58 \pm 0.14$ & $14.01 \pm 0.19$ \\
\hline Ash, \% & $0.96 \pm 0.01$ & $0.97 \pm 0.02$ & $0.97 \pm 0.01$ \\
\hline Calories, kcal & $2010.46 \pm 8.13$ & $1846.30 \pm 7.12$ & $1881.83 \pm 6.89$
\end{tabular}

Microstructural analysis of $m$. longissimus dorsi also confirmed the advantage of the AA genotype in terms of morphometric parameters. Thus, the rams had larger diameter of muscle fibers: the difference from AG and GG genotypes was 2.52 and 1.44 microns. In addition, there was a greater number of inter-fiber and inter-bundle inclusions of fat and a lower content of connective tissue, which gave the higher marbling score of 3.13 and 3.52 points respectively. The carriers of the genotype AA featured a larger area of the rib eye. Their superiority over the AG and GG genotypes was $1.36 \mathrm{~cm}^{2}$ and $1.74 \mathrm{~cm}^{2}$ (Table 4 , Figure 2).

Table 4. Microstructural analysis of $\boldsymbol{m}$. longissimus dorsi in rams of Altai Mountains breed of Prikatun type of different genotypes by the gene GDF9

\begin{tabular}{|c|c|c|c|c|c|}
\hline \multirow[b]{2}{*}{ Genotype } & \multicolumn{5}{|c|}{ Indices } \\
\hline & $\begin{array}{l}\text { Number of muscle } \\
\text { fibers, pcs. per } \mathbf{m m}^{2}\end{array}$ & $\begin{array}{l}\text { Diameter of muscle } \\
\text { fiber, } \mu \mathrm{m}\end{array}$ & $\begin{array}{l}\text { general "marbling } \\
\text { score", points }\end{array}$ & $\begin{array}{c}\text { Content of connective } \\
\text { tissue, } \%\end{array}$ & $\begin{array}{c}\text { Meatiness } \\
\text { (muscle eye area), } \mathrm{cm}^{2}\end{array}$ \\
\hline AA & $441.12 \pm 8.31$ & $28.67 \pm 1.55$ & $33.27 \pm 2.82$ & $8.45 \pm 0.31$ & $17.84 \pm 2,31$ \\
\hline AG & $448.39 \pm 9.67$ & $27.23 \pm 2.03$ & $30.14 \pm 0.76$ & $9.26 \pm 0.44$ & $16.48 \pm 1.79$ \\
\hline GG & $452.44 \pm 10.01$ & $26.15 \pm 1.88$ & $29.75 \pm 0.14$ & $9.41 \pm 0.37$ & $16.10 \pm 2.23$ \\
\hline
\end{tabular}
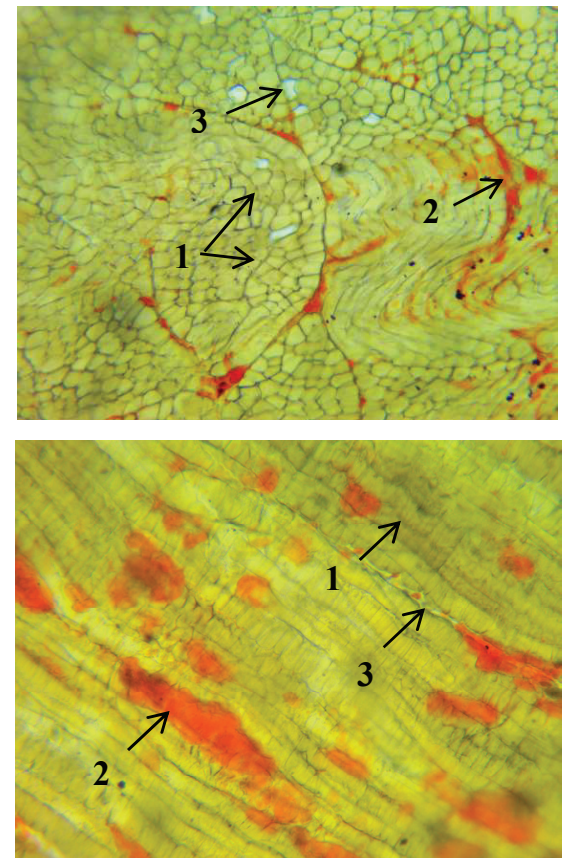

a)
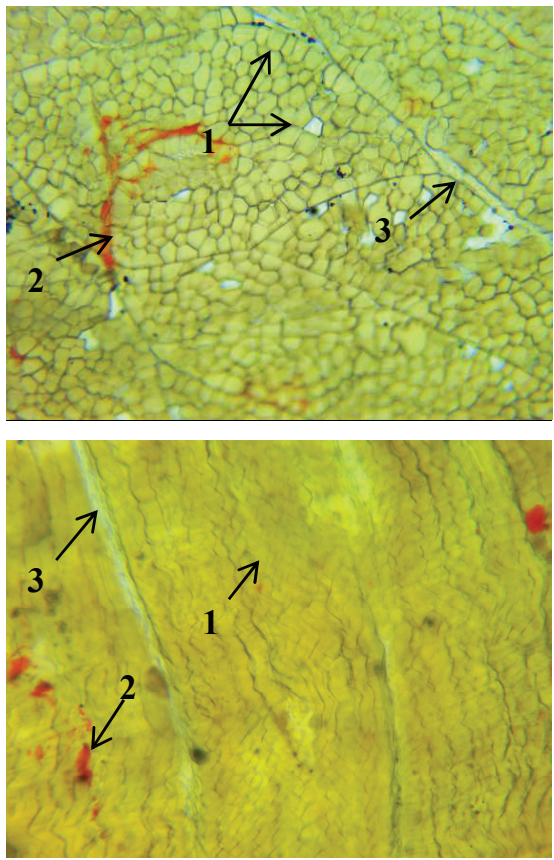

b)

Figure 2. Histological slices of $m$. longissimus dorsi of the rams of Altai Mountains breed of Prikatun type of different genotypes for the gene GDF9 a) AA-genotype b) GG-genotype (top — transverse slices; bottom — longitudinal slices) 1 - muscle fibers; 2 - fat tissue; 3 - connective tissue (color: hematoxylin Carracci and sudan III, magnified $10 \times 40$ ) 


\section{Conclusion}

In result of DNA typing, the polymorphism of the gene GDF9 and its relation with the indices of meat rate productivity in young sheep of Altai Mountains breed of Prikatun type were proven.

The most widespread in the breed is $G$ allele and the GG genotype respectively, but the results of our own research and the data of other authors defined that A allele is desirable for breeding to increase the reproductive qualities and productivity of sheep.

The study of the influence of different genotypes in the gene GDF9 on the indices of sheep meat rate productivity also allowed to confirming the positive effect of A allele.

It was revealed that the rams-carriers of AA genotype were superior to their peers of AG and GG genotypes in terms of pre-slaughter weight, carcass weight and yield, meat content ratio respectively by 1.62 and $7.01 \mathrm{~kg} ; 1.34$ and $3.98 \mathrm{~kg}(\mathrm{P}<0.05) ; 1.21$ and 1.86 abs. percent, 0.16 and 0.39 units $(\mathrm{P}<0.05)$.

The muscle tissue of rams of the desired genotype featured the highest content of protein, fat and, accordingly, energy value in comparison with the sheep of AG and GG genotypes. Animals of the AA genotype had the largest area of the rib eye and the diameter of the muscle fibers. The superiority over other genotypes achieved $1.55 \mathrm{~cm}^{2}$ and 1.98 microns in average. In addition a bigger number of inter-fiber and inter-bundle inclusions of fat and lower content of connective tissue stipulated the higher marbling score - by 3.32 points.

The obtained data prove the feasibility of studying the influence of the gene GDF9 on the meat rate productivity of sheep of other breeds, in particular, A alleles and AA and AG genotypes. This is also promising from the point of view that a range of researches have demonstrated that the AG genotype has a positive effect on fertile multiplicity of ewes $[20,21,22]$. All thing being equal, getting more lambs provides increase of mutton rate production, which largely determines the economic efficiency of meat sheep farming.

The results of this research allow to conclude that the genotyping of sheep of Altai Mountains of Prikatun type by the gene GDF9, the purposeful selection of parents in order to obtain more desirable genotypes, will not only increase the meat rate productivity of a herd as a whole, but also will contribute to the production of mutton of high quality parameters.

\section{REFERENCES}

1. Zinovieva, N. A., Kostyunina, O. V., Gladyr, E. A., Bannikova, A.D., Kharzinova, V.R., Larionova, P.V. at al. (2010). The role of DNA markers of indices of productivity of agricultural animals. Zootechniya, 1, 9-10. (In Russian)

2. Ibtisham, F., Zhang, L., Xiao, M., An, L., Ramzan, M. B., Nawab, A. at.al. (2017). Genomic selection and its application in animal breeding. Thai Journal of Veterinary Medicine, 47(3), 301-310 3. Georges, M., Charlier, C., Hayes, B. (2019). Harnessing genomic information for livestock improvement. Nature Reviews genetics, 20(3), 135-156. https://doi.org/10.1038/s41576-018-0082-2 4. Meuwissen, T., Hayes, B., Goddard, M. (2016). Genomic selection: A paradigm shift in animal breeding. Animal Frontiers, 6(1), 6-14. https://doi.org/ 10.2527/af.2016-0002

5. Kholmanov, A.M., Dankvert, S.A., Osadchaya, O. Yu. (2015). The number of sheep and the production of mutton in the world. Sheep, goats, wool business, 4, 15-20. (In Russian)

6. Wang, J., Zhou, H., Hu, J., Li, S., Luo, Y., Hickford, J. G. H. (2016). Two single nucleotide polymorphisms in the promoter of the ovine myostatin gene (MSTN) and their effect on growth and carcass muscle traits in New Zealand Romney sheep. Journal of Animal Breeding and genetics, 133(3), 219-226. https://doi. org/10.1111/jbg.12171

7. Arora, R., Yadav, H., Yadav, D. (2014). Identification of novel single nucleotide polymorphisms in candidate genes for mutton quality in Indian sheep. Animal Molecular Breeding, 12(5), 4551. https://doi.org/10.5376/amb.2014.04.0001

8. Fang, Q., Forrest, R. H., Zhou, H., Frampton, C. M., Hickford, J. G. H. (2013). Variation in exon 10 of the ovine calpain 3 gene (CAPN3) and its association with meat yield in New Zealand Romney sheep. Meat Science, 94(3), 388-390. https://doi. org/10.1016/j.meatsci.2013.03.015

9. Hajihosseinlo, A., Jafari, S., Ajdary, M. (2015). The relation of GH and LEP gene polymorphisms with fat-tail measurements (fat-tail dimensions) in fat-tailed Makooei breed of Iranian sheep. Advanced Biomedical Research, 4(1), 172181. https://doi. org/10.4103/2277-9175.163995

10. Saleem, A. H., Javed, K., Babar, M. E., Hussain, T., Ali, A., Ali, A. at al. (2018). Association of leptin gene polymorphism with growth rate in lohi sheep. Pakistan Journal of Zoology, 50(3), 1029-1033. https://doi.org/10.17582/journal.pjz/2018.50.3.1029.1033

11. Miar, Y., Salehi, A., Kolbehdari, D., Aleyasin, S.A. (2014). Application of myostatin in sheep breeding programs: A review. Molecular Cell Biology Research Communications, 3(1), 3343.
12. Gorlov, I., Kolosov, Y., Shirokova, N., Getmantseva, L., Slozhenkina, M., Mosolova, N. at al. (2017). Association of the growth hormone gene polymorphism with growth traits in Salsk sheep breed. Small Ruminant Research, 150, 11-14. https://doi. org/10.1016/j.smallrumres.2017.02.019

13. Gorlov, I. F., Shirokova, N. V., Natyrov, A. K., Kolosov, Y. A., Slozhenkina, M. I., Kolosov, A. Y. at al (2021). Growth hormone (GH) gene polymorphism and its association with meat productivity in two rough wool sheep breeds grown in Russia's dry zone. International Journal of Agriculture and Biology, 25(1), 255-259. https://doi.org/10.17957/IJAB/15.1664

14. Armstrong, E., Ciappesoni, G., Iriarte, W., Da Silva, C., Macedo, F., Navajas, E. A. at al. (2018). Novel genetic polymorphisms associated with carcass traits in grazing texel sheep. Meat Science, 145, 202-208. https://doi.org/10.1016/j.meatsci.2018.06.014 15. Akhatayeva, Z., Li, H., Mao, C., Cheng, H., Zhang, G., Jiang, F. at al. (2020). Detecting novel indel variants within the GHR gene and their associations with growth traits in luxi blackhead sheep. Animal Biotechnology, https://doi.org/10.1080/10495398.202 0.1784184

16. Jia, J. L., Zhang, L. P., Wu, J. P., Ha, Z. J., Li, W. W. (2014). Study of the correlation between GH gene polymorphism and growth traits in sheep. genetics and Molecular Research, 13(3), 7190-7200. https://doi.org/10.4238/2014.September.5.5

17. Valeh, M.V., Tahmoorespour, M., Ansari, M., Nassiry, M.R., Karimi, D., Taheri, A. (2012). Association of growth traits with SSCP polymorphisms at the growth hormone receptor (GHR) and growth hormone releasing hormone receptor (GHRHR) genes in the Baluchi sheep. Journal of Animal and Veterinary Advances, 8(6), 1063-1069.

18. Meira, A. N., Montenegro, H., Coutinho, L. L., Mourão, G. B., Azevedo, H. C., Muniz, E. N. at al. (2019). Single nucleotide polymorphisms in the growth hormone and IGF type-1 (IGF1) genes associated with carcass traits in Santa Ines sheep. Animal, 13(3), 460-468. https://doi.org/10.1017/S1751731118001362

19. Wu, M., Zhao, H., Tang, X., Li, Q., Yi, X., Liu, S., Sun, X. (2020). Novel indels of GHR, GHRH, GHRHR and their association with growth traits in seven Chinese sheep breeds. Animals, 10(10), 1-13. https://doi.org/ 10.3390/ani10101883

20. Wang, F., Chu, M., Pan, L., Wang, X., He, X., Zhang, R. at al. (2021). Polymorphism detection of gene GDF9 and its association with litter size in Luzhong mutton sheep (ovis aries). Animals, 11(2), 1-11. https://doi.org/10.3390/ani11020571 
21. Li, Y., Jin, W., Wang, Y., Zhang, J., Meng, C., Wang, H. at al. (2020). Three complete linkage SNPs of gene GDF9 affect the litter size probably mediated by OCT1 in hu sheep. DNA and Cell Biology, 39(4), 563-571. https://doi.org/10.1089/dna.2019.4984 22. Chu, M. X., Yang, J., Feng, T., Cao, G. L., Fang, L., Di, R. at al. (2011). GDF9 as a candidate gene for prolificacy of small tail Han sheep. Molecular Biology Reports, 38(8), 5199-5204. https://doi.org/10.1007/s11033-010-0670-5

23. Pokharel, K., Peippo, J., Honkatukia, M., Seppälä, A., Rautiainen, J., Ghanem, N. at al. (2018). Integrated ovarian mRNA and miRNA transcriptome profiling characterizes the genetic basis of prolificacy traits in sheep (ovis aries). BMC Genomics, 19(1). https://doi.org/10.1186/s12864-017-4400-4

24. Pan, Z., Wang, X., Di, R., Liu, Q., Hu, W., Cao, X. at al. (2018). A 5-methylcytosine site of growth differentiation factor 9 (Gdf9) gene affects its tissue-specific expression in sheep. Animals, 8(11). https://doi.org/10.3390/ani8110200

25. Getmantseva, L., Bakoev, N., Shirokova, N., Kolosova, M., Bakoev, S., Kolosov, A. at al. (2019). Effect of the gene GDF9 on the weight of lambs at birth. Bulgarian Journal of Agricultural Science, 25(1), 153-157.

26. Al-Khuzai, F. L. J., Ahmed, J. R. (2019). Polymorphism of GDF9 (exon-1) gene and its association with milk production and prolificacy of awassi sheep. Plant Archives, 19(2), 4037-4040.
27. Podkorytov, A. T., Selionova, M. I., Podkorytov, N. A, Podkorytov, A. A. (2018). Sheep and goat breeding in the Altai Republic status, problems, solution. Zootechniya, 10, 8-11. (In Russian) 28. Khvylya, S.I., Pchelkina, V.A., Burlakova, S.S. (2011). Standardized histological methods for assessing the quality of meat and meat products. Vsyo o myase, 6, 32-35. (In Russian) 29. Selionova, M. I. Chizhova, L. N., Mikhailenko, A. K., Kvitko, Yu. D., et al. (2015). System of comprehensive assessment of the genetic potential of breeding animals, Stavropol, VNIIOK. $-50 \mathrm{p}$. (In Russian)

30. Selionova, M.I., Chizhova, L.N., Surzhikova, E.S., Podkorytov, N.A., Podkorytov, A.T., Voblikova, T.V. (2020). Meat productivity of sheep of Altai Mountains breed of different genotypes according to the CAST and gene GDF9s. IOP Conference Series: Earth and Environmental Science, 613(1), Article 012130. https://doi. org/10.1088/1755-1315/613/1/012130

31. Kolosov, Y.A., Getmantseva, L.V., Shirockova, N.V., Klimenko, A., Bakoev, S. Y., Usatov, A.V. at al. (2015). Polymorphism of the gene GDF9 in Russian sheep breeds. Journal of Cytology \& Histology, 6(1). https://doi.org/10.4172/2157-7099.1000305

32. Bahrami, Y., Bahrami, S., Mohammadi, H. R., Chekani-Azar, V., Mousavizadeh, S.A. (2014). The polymorphism of GDF-9 gene in Hisari sheep. Biological Forum - An International Journal, 6(2), 46-52.

\section{AUTHOR INFORMATION}

Marina I. Selionova - doctor of biological sciences, professor, head of the Department of breeding, genetics and animal biotechnology, Russian State Agrarian University — Moscow Timiryazev Agricultural Academy. 127550, Moscow, Timiryazevskaya str., 49. Tel.: +7-968-266-33-03. E-mail: selionova@rgau-msha.ru

ORCID: https://orcid.org/0000-0002-9501-8080

* corresponding author

Nikolai A. Podkorytov - candidate of agricultural sciences, head of the Department of Sheep breeding, Altai Mountains Research Institute of Agriculture - Branch of the Federal Altai Scientific Center of Agrobiotechnology, 649100, Altai Republic, Mayma w., Katunskaya str., 2, Tel.: +7-913-237-16-76. E-mail: nikola.zolotoy@mail.ru

ORCID: https://orcid.org/0000-0001-7370-2167

All authors bear responsibility for the work and presented data.

All authors made an equal contribution to the work.

The authors were equally involved in writing the manuscript and bear the equal responsibility for plagiarism.

The authors declare no conflict of interest/

Received 10.02.2021 Accepted in revised 16.03.2021 Accepted for publication 23.03.2021 